\title{
SBQ APRESENTA CANDIDATURA DO BRASIL PARA SEDIAR O CONGRESSO MUNDIAL DE QUÍMICA DA IUPAC EM 2017
}

Receber mais um grande evento no Brasil, três anos depois da Copa do Mundo de 2014 e um ano após a realização dos Jogos Olímpicos de 2016, é a grande aspiração da SBQ ao apresentar a candidatura do Brasil como país-sede do $46^{\circ}$ Congresso Mundial de Química e 49a Assembleia Geral da IUPAC, em 2017. A proposta vem ao encontro dos objetivos da SBQ de desenvolver e fortalecer a Química no país, trazendo o maior evento de Química do mundo pela primeira vez para a América do Sul.

As ações da SBQ em prol da IUPAC 2017 se iniciaram na gestão passada, em 2010. A primeira etapa do processo, que envolveu vários meses de articulações e negociações, culminou, em 2011, com a formalização do pedido de registro de candidatura do Brasil pelo então presidente da SBQ, professor César Zucco. A proposta enviada à IUPAC foi aprovada e, consequentemente, permitiu a consideração do Brasil na segunda etapa do processo de escolha do país-sede da edição de 2017 do evento. Este trabalho está sendo conduzido de forma contínua pela atual D\&C (diretoria e conselho) da SBQ. Um grande passo neste processo foi dado com o lançamento, em janeiro de 2013, do site da candidatura do Brasil ("46 ${ }^{\text {th }}$ IUPAC World Chemistry Congress São Paulo, Brazil - 2017 - Candidate City”, disponível em nossa página: http://www.sbq.org.br/IUPAC2017), que contém um vídeo oficial especialmente desenvolvido para esta finalidade, entre outras informações importantes.

A força da candidatura do Brasil se sustenta em alguns pilares principais, fundamentados em aspectos científicos, sociais e históricos, que se somam a outros elementos que têm caracterizado a nossa capacidade de organizar um evento deste porte. Somente desta forma, com planejamento, organização e execução eficazes, conquistaremos o respeito internacional necessário para atrair bons apoios à nossa candidatura. $\mathrm{O}$ momento final deste processo será em agosto deste ano, em Istambul na Turquia (durante o " $44^{\text {th }}$ IUPAC World Chemistry Congress"), quando será escolhido o país-sede do evento, em uma competição direta com a Austrália. A escolha do país-sede do congresso da IUPAC de 2019 será realizada também nesta oportunidade, em uma disputa entre China e França.

É fundamental entender as razões e os motivos deste grande objetivo. Acreditamos que o país só tem a ganhar ao acolher os químicos de todo o mundo. Receber um evento do porte da IUPAC 2017, com sua tradição e história, dará continuidade ao processo de internacionalização da SBQ, permitindo a inserção da América do Sul e, consequentemente, do Brasil, no mapa mundial da Química, enfatizando sempre o papel da SBQ como a principal interlocutora dos assuntos químicos no país. É oportuno observar que os Congressos Mundiais de Química foram realizados 45 vezes: 31 na Europa, 7 na América do Norte, 5 na Ásia e 2 na Oceania (considerando os congressos de 2013 na Turquia e de 2015 na Coréia do Sul).

O congresso da IUPAC em 2017 no Brasil ocorrerá em conjunto com a $40^{a}$ Reunião Anual da SBQ, em uma ocasião muito especial em meio às comemorações dos 40 anos da fundação de nossa Sociedade. Sem dúvida, esta feliz coincidência colocará a SBQ e o Brasil em evidência no cenário internacional, representando uma grande conquista da Química brasileira. Além da oportunidade única de congregar jovens químicos de todos os continentes, o evento reunirá um número expressivo de profissionais da área de Química, da academia e da indústria, entre professores, pesquisadores, pós-doutorandos, técnicos e estudantes dos mais diversos níveis.

O incremento da participação brasileira nas atividades da IUPAC vem ocorrendo em uma época marcada pela preocupação com o meio-ambiente, as mudanças climáticas e a necessidade humana de obter cada vez mais alimentos, energia e matérias-primas a partir da biomassa e de minerais abundantes. Tanto a produção quanto o uso da biomassa dependem criticamente do conhecimento químico que é consolidado e normatizado pelos vários comitês da IUPAC. Para muitos, essa atividade pode parecer apenas burocrática, mas é essencial para a qualidade da linguagem química e, portanto, para a comunicação e discussão sobre os fenômenos químicos. Por outro lado, o papel destacado do Brasil como grande produtor de alimentos, energia e matérias-primas da biomassa lhe dá a oportunidade e a responsabilidade de liderar um dos mais importantes processos humanos em todos os tempos, o que deve ser feito dentro de muitas instâncias globais, tais como a IUPAC.

O Brasil é ainda considerado muito isolado em vários aspectos da vida econômica e cultural. Praticamos, no passado, políticas que nos afastaram de grandes correntes da evolução científica e tecnológica, o que nos causa grandes prejuízos até hoje. É notório que a maioria dos estudantes universitários do país não domina a língua inglesa ou algum outro idioma relevante, o que foi evidenciado pela recente redução nas exigências de proficiência em língua estrangeira do programa Ciência sem Fronteiras do CNPq. Por outro lado, para muitas pessoas em todo o mundo o Brasil ainda é o país da cafusa (uma união das palavras carnaval, futebol e samba, que foi utilizada para batizar a bola oficial da Copa das Confederações). Certamente, poderíamos associar a estes três símbolos da cultura brasileira nossas muitas outras e relevantes realizações culturais, científicas, tecnológicas e econômicas que, infelizmente, ainda são pouco conhecidas.

Ao receber no Brasil cientistas, estudantes e profissionais da Química de todos os continentes, poderemos compartilhar nosso entusiasmo pela Química e pelo futuro. Para sediar o evento foi escolhida a cidade de São Paulo, uma metrópole multicultural que não se limita a uma população diversificada. Possui infraestrutura e hotéis de primeiro mundo, excelente gastronomia, museus de classe mundial e muita cultura, música e shows, além de grande variedade de atrações para todas as culturas, idades, gostos e orçamentos. Temos certeza de que realizaremos um evento inesquecível, energizado pela paixão, hospitalidade e criatividade do povo brasileiro.

Adriano D. Andricopulo Fernando Galembeck

Vitor F. Ferreira 